\title{
PENGARUH KEMAMPUAN KERJA PEGAWAI DAN KUALITAS PELAYANAN PUBLIK TERHADAP KEPUASAN MASYARAKAT DALAM MENERIMA PELAYANAN PUBLIK DI KECAMATAN KARAWACI KOTA TANGERANG
}

\author{
${ }^{1}$ Elga Nor Wicaksono, ${ }^{1}$ Nursusanto, ${ }^{2}$ Jarnawi Afgani Dahlan \\ ${ }^{1}$ Pascasarjana UNIS Tangerang \\ ${ }^{2}$ Departemen Pendidikan Matematika UPI \\ Email: elganorw@gmail.com
}

\begin{abstract}
This study aims to determine and explain the effect of employee work ability and quality of service to public satisfaction in receiving public service at Karawaci District Tangerang City. For his research is the capability of the variable $\left(X_{1)}\right.$, quality of service $\left(X_{2}\right)$ and community satisfaction $(Y)$. The research method used is a quantitative method with an associative type that explains the relationship between independent variables with the dependent variable. The survey was conducted on 100 communities receiving services in Kecamatan Karawaci Tangerang City from the total community as many as 132,617 people over the age of 18 years and literature study as a supporter of empirical study. Hypothesis testing is done through data processing using SPSS for Windows program package version 20.00 year 2013 with static correlation analysis method, determination coefficient and linear regression. The validity of the instrument is done through validity, realibility, normality and linearity of data. Based on the analysis result, it can be concluded that the ability of employee's ability to influence the satisfaction of the community in Kecamatan Karawaci amounted to $32.95 \%$. The ability of service quality in influencing community satisfaction in Kecamatan Karawaci amounted to $44.22 \%$. The ability of employee job satisfaction and service quality in influencing the community satisfaction in Kecamatan Karawaci amounted to 52.00\%. Suggestion from this research is Head of Karawaci must pay more attention to the dimensions in research variables so that public satisfaction in receiving public service in Kecamatan Karawaci can be improved. In addition, the evaluation of community satisfaction with the acceptance of the public service should be performed regularly with the parameters that are tailored to the Regulation of the Minister of Administrative Reform and Bureaucratic Reform No. 16 Year 2014 on Guidelines for Public Satisfaction Survey Of Public Service Operator.
\end{abstract}

Keywords: work ability, quality of service, public satisfaction

\section{A. Pendahuluan}

Pelayanan merupakan tugas utama yang hakiki dari sosok aparatur, sebagai abdi negara dan abdi masyarakat. Tugas ini telah jelas digariskan dalam pembukaan UUD 1945 alinea keempat, yang diperjelas lagi dalam Keputusan Menteri Pendayagunaan Aparatur Negara No. 25 tahun 2004 yang menguraikan pedoman umum penyelenggaraan pelayanan publik. Pelayanan sebagai proses pemenuhan kebutuhan melalui aktivitas orang lain secara lansung, merupakan konsep yang senantiasa aktual dalam berbagai aspek kelembagaan.
Bukan hanya pada organisasi bisnis, tetapi telah berkembang lebih luas pada tatanan organisasi pemerintah.

Kemudian pelayanan publik juga memiliki dasar hukum Undang-Undang Nomor 25 tahun 2009 tentang Pelayanan Publik. Menurut UU tersebut, Pelayanan publik adalah kegiatan atau rangkaian kegiatan dalam rangka pemenuhan kebutuhan pelayanan sesuai dengan peraturan perundang-undangan bagi setiap warga negara dan penduduk atas barang, jasa, dan/atau pelayanan administratif yang disediakan oleh penyelenggara pelayanan publik. Ruang 
lingkup pelayanan publik menurut Undang-Undang Pelayanan Publik meliputi pelayanan barang publik dan jasa publik serta pelayanan administratif yang diatur dalam peraturan perundangundangan.

Dewasa ini kehidupan masyarakat mengalami banyak perubahan sebagai akibat dari kemajuan yang telah dicapai dalam proses pembangunan sebelumnya dan kemajuan yang pesat dalam ilmu pengetahuan dan teknologi. Perubahan yang dapat dirasakan sekarang ini adalah terjadinya perubahan pola pikir masyarakat ke arah yang semakin kritis. Hal itu dimungkinkan, karena semakin hari warga masyarakat semakin cerdas dan semakin memahami hak dan kewajibannya sebagai warga.

Kondisi masyarakat yang demikian menuntut hadirnya pemerintah yang mampu memenuhi berbagai tuntutan kebutuhan dalam segala aspek kehidupan mereka, terutama dalam mendapatkan pelayanan yang sebaikbaiknya dari pemerintah. Dalam kaitannya itu (Rasyid 2007:11) mengemukakan bahwa : Pemerintah modern, dengan kata lain, pada hakekatnya adalah pelayanan kepada masyarakat. Pemerintah tidaklah diadakan untuk melayani dirinya sendiri, tetapi untuk melayani masyarakat. Memungkinkan setiap anggota masyarakat mengembangkan kemampuan dan kreativitasnya demi mencapai kemajuan bersama.

Pemberian palayanan yang memenuhi standar yang telah ditetapkan memang menjadi bagian yang perlu dicermati. Saat ini masih sering dirasakan bahwa kualitas pelayanan minimum sekalipun masih jauh dari harapan masyarakat. Yang lebih memprihatinkan lagi, masyarakat hampir sama sekali tidak memahami secara pasti tentang pelayanan yang seharusnya diterima dan sesuai dengan prosedur pelayanan yang baku oleh pemerintah. Masyarakatpun enggan mengadukan apabila menerima pelayanan yang buruk, bahkan hampir pasti mereka pasrah menerima layanan seadanya. Kenyataan semacam ini terdorong oleh sifat public goods menjadi monopoli pemerintah khususnya dinas/instansi pemerintah daerah dan hampir tidak ada pembanding dari pihak lain. Praktek semacam ini menciptakan kondisi yang merendahkan posisi tawar dari masyarakat sebagai penggunan jasa pelayanan dari pemerintah, sehingga memaksa masyarakat mau tidak mau menerima dan menikmati pelayanan yang kurang memadai tanpa protes.

Dalam

penyelenggaraan pelayanan oleh pemerintah, khususnya di Kecamatan Karawai Kota Tangerang, kepuasan masyarakat merupakan tolak ukur keberhasilan pemerintah Kecamatan Karawaci dalam menyediakan pelayanan publik. Dengan cara mengetahui apakah layanan kepada masyarakat tersebut sudah terpenuhi dan sesuai dengan yang diwajibkan oleh Pemerintah Kota Tangerang yang termuat dalam Standar Pelayanan Minimal terhadap kebutuhan masyarakat dan harapan atas layanan yang masyarakat terima yang memperhatikan kualitas pelayanan yang diberikan oleh pemerintah Kecamatan Karawaci relatif terjangkau dan mutu pelayanan itu sendiri memiliki muatan yang transparan, adil, partisipatif dan dapat dipertanggungjawabkan produk layananannya.

Fasilitas pelayanan yang tidak memadai, menimbulkan keterlambatan mengwujudkan hasil kerja nyata, dan tanpa tersedianya fasilitas yang mencukupi dalam organisasi maka pelayanan tidak terlaksana dengan maksimal. Setiap pekerjaan memerlukan fasilitas untuk memudahkan pelaksanaan tugas. Fasilitas disediakan guna mendukung perkerjaan manusia dalam mencapai tujuan organisasi yang diharapkan.

Dari uraian di atas, maka tjuan yang ingin dicapai pada penelitian ini adalah untuk mendapatkan pemahaman 
lebih mendalam berkenaan upaya-upaya peningkatan pelayanan publik yang dilaksanakan oleh suatu instansi di lingkungan kerja Pemerintahan Kota Tangerang dengan mengukur tingkat kepuasan masyarakat selaku penerima layanan dan kaitannya dengan kemampuan kerja pegawai dan fasilitas pelayanan yang tersedia di Kantor Kecamatan Karawaci Kota Tangerang, sehingga hasil penelitian ini menjadi sebuah kajian ilmiah dan berarti bagi masyarakat dan Pemerintah Kota Tangerang, khususnya di Pemerintah Kecamatan Karawaci yang melaksanakan pelayanan publik.

\section{B. Metode Penelitian}

Metode penelitian yang digunakan adalah menggunakan metode kuantitatif, yaitu menggunakan perhitungan statistik sebagai dasar pengolahan dan alat analisis data. Adapun metode kuantitatif yang digunakan termasuk ke dalam jenis asosiatif (hubungan), sebab variabel terdiri dari dua, yaitu variabel bebas (variabel kemampuan kerja pegawai dan variabel kualitas pelayanan publik) dan variabel terikat (kepuasan masyarakat). Dengan penelitian ini maka akan dapat dibangun suatu teori yang dapat berfungsi untuk menjelaskan, meramalkan, dan mengontrol suatu gejala yang terjadi dalam obyek penelitian.

Populasi dalam penelitian ini adalah masyarakat yang menerima pelayanan di Kecamatan Karawaci dan berusia di atas 18 tahun yang berjumlah 132.617 orang, yang terdiri dari 66.310 laki-laki dan 66.307 perempuan. Sedangkan ukuran sampelnya sebesar 100 orang masyarakat yang diambil secara acak dengan menggunakan rumus Slovin dengan error sampel sebesar $10 \%$.

Sejalan dengan definisi konsep dan operasional variabel maka data primer penelitian adalah merupakan jawaban responden atas pengisian kuesioner. Daftar Pertanyaan (kuesioner), yaitu sejumlah pertanyaan yang diberikan kepada responden sekitar permasalahan penelitian. Dengan demikian dalam pengumpulan data peneliti akan mempergunakan alat bantu daftar pertanyaan berupa angket dan lembar pengamatan yang keduanya bersifat terstruktur.

Teknik analisis yang digunakan adalah korelasi produk moment, koefisien determinasi dan regresi linear yang dianalisis baik secara sederhana ataupun ganda.

$$
\begin{aligned}
& \text { Rumus Korelasi } \\
& \text { Sederhana Rumus Korelasi } \\
& \text { Ganda }
\end{aligned}
$$

\section{Hasil Penelitian dan Pembahasan}

Secara deskriptif, hasil dari responden tentang kemampuan kerja adalah sebagai berikut

\section{Tabel 1. Jawaban Responden tentang Kemampuan Kerja}

\begin{tabular}{clccc}
\hline $\begin{array}{c}\text { N } \\
\text { o. }\end{array}$ & $\begin{array}{c}\text { Pilihan } \\
\text { Jawaban }\end{array}$ & $\begin{array}{c}\text { Frekue } \\
\text { nsi }\end{array}$ & $\begin{array}{c}\text { Faktor } \\
\text { Konversi }\end{array}$ & $\begin{array}{c}\text { Juml } \\
\text { ah }\end{array}$ \\
\hline 1 & Sangat & & & \\
& Setuju & 86 & 5 & 430 \\
2 & Setuju & 235 & 4 & 940 \\
\hline & Jumlah & & $\mathbf{1 . 3 7 0}$ \\
\hline
\end{tabular}

Sumber : Hasil Analisis Data

Kuantitatif Kuesioner, Penelitian 2017

Hasil perbandingan antara skor total jawaban responden dengan skor total apabila menjawab pilihan selalu dapat dijadikan pedoman untuk melihat penilaian tingkat kemampuan kerja pegawai di Kecamatan Karawaci Kota Tangerang. Adapun hasil persentase tersebut adalah. Adapun hasil persentase tersebut adalah : \% kemampuan kerja pegawai $=[1.370: 2.000] \times 100 \%=$ $68,50 \%$. Berdasarkan hasil perbandingan 
di atas, dapat diketahui bahwa tingkat kemampuan kerja pegawai di Kecamatan Karawaci Kota Tangerang nilainya adalah 68,50 \%. Dengan demikian dapat digambarkan bahwa tingkat kemampuan kerja pegawai di Kecamatan Karawaci Kota Tangerang dapat dikategorikan sudah cukup baik, mengingat hasil persen perbandingan menunjukkan berada di atas $50 \%$ dari $100 \%$ nilai yang diperhitungkan.

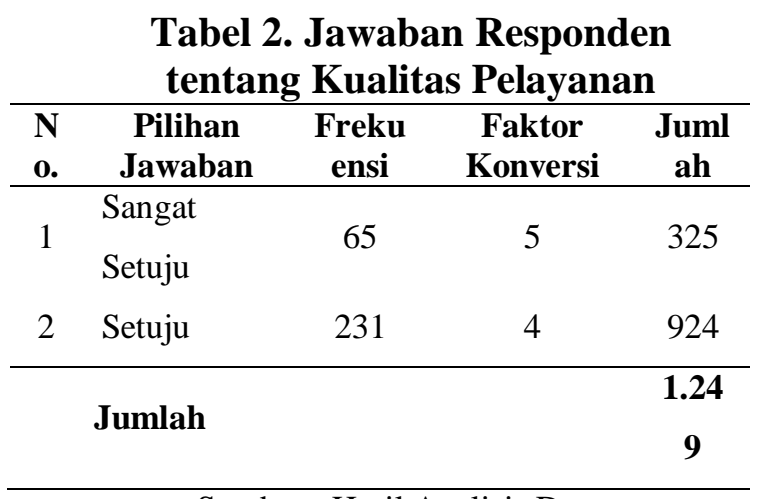

Sumber : Hasil Analisis Data

Kuantitatif Kuesioner, Penelitian 2017

Adapun hasil persentase kualitas pelayanantersebut adalah : \% kualitas pelayanan $=[1.249: 2.000] \times 100 \%=$ $62,45 \%$. Berdasarkan hasil perbandingan di atas, dapat diketahui bahwa kondisi kualitas pelayanan saat ini di Kecamatan Karawaci Kota Tangerang nilainya adalah $62,45 \%$. Dengan demikian dapat digambarkan bahwa tingkat kualitas pelayanan di Kecamatan Karawaci Kota Tangerang dapat dikategorikan sudah cukup baik, mengingat hasil persen perbandingan menunjukkan berada di atas $50 \%$ dari $100 \%$ nilai yang diperhitungkan.

Tabel 3. Jawaban Responden tentang Kepuasan Masyarakat

\begin{tabular}{clccc}
\hline $\begin{array}{c}\text { N } \\
\text { o. }\end{array}$ & $\begin{array}{c}\text { Pilihan } \\
\text { Jawaban }\end{array}$ & $\begin{array}{c}\text { Freku } \\
\text { ensi }\end{array}$ & $\begin{array}{c}\text { Faktor } \\
\text { Konversi }\end{array}$ & $\begin{array}{c}\text { Juml } \\
\text { ah }\end{array}$ \\
\hline 1 & $\begin{array}{l}\text { Sangat } \\
\text { Setuju }\end{array}$ & 43 & 5 & 215 \\
2 & Setuju & 218 & 4 & 872 \\
\hline & Jumlah & & & $\mathbf{1 . 0 8}$
\end{tabular}

Vol 2, No 1 (2020)

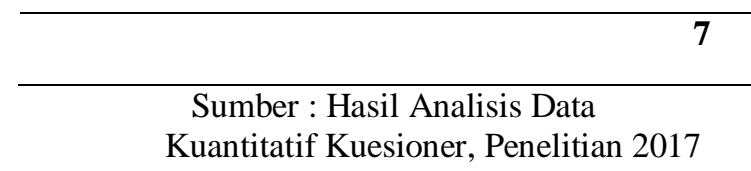

Kuantitatif Kuesioner, Penelitian 2017

Adapun hasil persentase kepuasan masyarakat tersebut adalah : \% kepuasan masyarakat $=[1.087: 2.000] \times 100 \%=$ $54,35 \%$. Berdasarkan hasil perbandingan di atas, dapat diketahui bahwa tingkat kepuasan masyarakat atas pemberian pelayanan di Kecamatan Karawaci Kota Tangerang nilainya adalah 54,35\%. Dengan demikian dapat digambarkan bahwa tingkat kepuasan masyarakat atas pelayanan di Kecamatan Karawaci Kota Tangerang dapat dikategorikan sudah cukup baik, mengingat hasil persen perbandingan menunjukkan berada di atas $50 \%$.

Hasil berikutnya adalah hasil perhitungan untuk persayaratan analisis inferensial.

\section{Tabel 4. Hasil Perhitungan Persyaratan Analisis Data}

\begin{tabular}{|c|c|c|c|}
\hline No & Jenis Uji & Hasil & Kesimpulan \\
\hline 1. & $\begin{array}{l}\text { Normalitas } \\
\text { Data }\end{array}$ & $\begin{array}{l}\text { Nilai } \\
\text { Kolmogorov- } \\
\text { Smirnov Z } \\
\text { memiliki nilai } \\
\text { asymptot } \\
\text { kurang dari } 5 \\
\%\end{array}$ & $\begin{array}{l}\text { Semua } \\
\text { jawaban } \\
\text { responden } \\
\text { dari } \\
\text { variabel } \\
\text { dinyatakan } \\
\text { normal }\end{array}$ \\
\hline 2. & $\begin{array}{l}\text { Linearitas } \\
\text { Data }\end{array}$ & $\begin{array}{l}\text { Nilai linearity } \\
\text { adalah sebesar } \\
50,389 \text { dan } \\
80,110 \text { dengan } \\
\text { nilai signifikan } \\
0,000 \text { dan } \\
0,000 \text {. }\end{array}$ & $\begin{array}{l}\text { Data antara } \\
2 \text { variabel } \\
\text { bebas } \\
\text { dengan } \\
\text { variabel } \\
\text { terikat } \\
\text { berhubungan } \\
\text { secara linear }\end{array}$ \\
\hline
\end{tabular}

\section{Hasil Perhitungan Pengujian Hipotesis}

Hasil perhitungan korelasi baik sederhana ataupun ganda disajikan dalam tabel di halaman berikut ini. 
Tabel 5. Hasil Perhitungan Korelasi

\begin{tabular}{|c|c|c|}
\hline Variabel & Keterangan & $\mathbf{Y}$ \\
\hline \multirow{3}{*}{$\mathrm{X}_{1} \Rightarrow \mathrm{Y}$} & Pearson Correlation & $0.574^{* *}$ \\
\hline & Sig. (2-tailed) & 0.000 \\
\hline & $\mathrm{N}$ & 100 \\
\hline \multirow{3}{*}{$X_{2} \Rightarrow Y$} & Pearson Correlation & $0.665^{* *}$ \\
\hline & Sig. (2-tailed) & 0.000 \\
\hline & $\mathrm{N}$ & 100 \\
\hline \multirow{3}{*}{$\mathrm{X}_{1} \& \mathrm{X}_{2} \Rightarrow \mathrm{Y}$} & Pearson Correlation & 0,721 \\
\hline & Sig. (2-tailed) & 0,000 \\
\hline & $\mathrm{N}$ & 100 \\
\hline
\end{tabular}

Kuantitatif Kuesioner, Penelitian 2017

Hasil analisis antara variabel kemampuan kerja pegawai $\left(\mathrm{X}_{1}\right)$ dengan variabel kepuasan masyarakat (Y) sebesar 0,574 yang signifikan hasilnya pada selang kepercayaaan lebih dari $95 \%$ $(\alpha=0,000)$. sehingga untuk pengujian hipotesis pertama yang menyatakan bahwa : "Terdapat pengaruh kemampuan kerja pegawai terhadap kepuasan masyarakat dalam menerima pelayanan publik pada Kecamatan Karawaci Kota Tangerang", kesimpulannya dapat diterima pada selang kepercayaan 95\%.

Hasil analisis antara variabel kualitas pelayanan publik $\left(\mathrm{X}_{2}\right)$ dengan variabel kepuasan masyarakat $(\mathrm{Y})$ sebesar 0,665 yang signifikan pada selang kepercayaan lebih dari $95 \%(\alpha=0,003)$. Sehingga untuk pengujian hipotesis kedua yang menyatakan : "Terdapat pengaruh kualitas pelayanan publik terhadap kepuasan masyarakat dalam menerima pelayanan publik pada Kecamatan Karawaci Kota Tangerang”, kesimpulannya dapat diterima pada selang kepercayaan $95 \%$.

Hasil analisis antara antara variabel antara variabel kemampuan kerja pegawai $\left(\mathrm{X}_{1}\right)$ dan variabel kualitas pelayanan publik $\left(\mathrm{X}_{2}\right)$ dengan variabel kepuasan masyarakat (Y) adalah sebesar 0,721 yang signifikan pada selang kepercayaan $95 \%(\alpha=0,0030$. Dengan hasil tersebut dapat disimpulkan bahwa hipotesis penelitian ketiga yang menyatakan : "Terdapat pengaruh kemampuan kerja pegawai dan kualitas pelayanan publik secara bersama-sama terhadap kepuasan masyarakat dalam menerima pelayanan publik pada Kecamatan Karawaci Kota Tangerang", dapat terbukti pada selang kepercayaan $95 \%$.

\section{Pembahasan}

Hasil korelasi parsial antara kemampuan kerja pegawai yang dikendalikan oleh kualitas pelayanan publik terhadap kepuasan masyarakat dalam menerima pelayanan publik pada Kecamatan Karawaci Kota Tangerang disajikan dalam tabel berikut.

\section{Tabel 6. Hasil Perhitungan Korelasi Parsial}

\begin{tabular}{|c|c|c|c|c|}
\hline \multicolumn{3}{|c|}{ Control Variables } & KK & $\mathrm{KM}$ \\
\hline \multirow[t]{6}{*}{$\overline{\mathrm{KP}}$} & KK & Correlation & 1.000 & .372 \\
\hline & & $\begin{array}{l}\text { Significance (2- } \\
\text { tailed) }\end{array}$ & . & .000 \\
\hline & & df & 0 & 97 \\
\hline & KM & Correlation & .372 & 1.000 \\
\hline & & $\begin{array}{l}\text { Significance (2- } \\
\text { tailed) }\end{array}$ & .000 & . \\
\hline & & df & 97 & 0 \\
\hline
\end{tabular}

\begin{tabular}{|c|c|c|c|c|}
\hline \multicolumn{3}{|c|}{ Control Variables } & \multirow{2}{*}{$\begin{array}{c}\mathrm{KP} \\
1.000\end{array}$} & \multirow{2}{*}{$\begin{array}{l}\mathrm{KM} \\
.534\end{array}$} \\
\hline$\overline{\mathrm{KK}}$ & KP & Correlation & & \\
\hline & & $\begin{array}{l}\text { Significance (2- } \\
\text { tailed) }\end{array}$ & . & .000 \\
\hline & & df & 0 & 97 \\
\hline & $\overline{\mathrm{KM}}$ & Correlation & .534 & 1.000 \\
\hline & & $\begin{array}{l}\text { Significance (2- } \\
\text { tailed) }\end{array}$ & .000 & \\
\hline & & $\mathrm{df}$ & 97 & 0 \\
\hline
\end{tabular}

Kuantitatif Kuesioner, Penelitian 2017

Keterangan :

$\Rightarrow \mathrm{KK}$ : Variabel Kemampuan Kerja

$\Rightarrow \mathrm{KP}:$ Variabel Kualitas Pelayanan

$\Rightarrow \mathrm{KM}$ : Variabel Kepuasan Masyarakat 
Pada tabel teratas, diperoleh hasil perhitungan korelasi parsial dengan nilai sebesar 0,372 dengan tingkat siginifikasi sebesar 0,000. Dari nilai korelasi parsial tersebut dapat diinterpretasikan bahwa pengaruh kemampuan kerja pegawai terhadap kepuasan masyarakat di Kecamatan Karawaci Kota Tangerang memiliki pengaruh yang signifikan jika dikendalikan oleh kualitas pelayanan. Sedangkan pada tabel dibawahnya menerangkan bahwa pengaruh kualitas pelayanan terhadap kepuasan masyarakat di Karawaci Kota Tangerang memiliki pengaruh yang signifikan jika dikendalikan oleh kemampuan kerja kerja dengan nilai korelasi sebesar 0,534 dengan tingkat siginifikasi sebesar 0,000.

Selanjutnya untuk mengetahui besarnya pengaruh antara variabel bebas terhadap variabel terikatnya maka digunakan rumus koefisien determinasi, yang hasilnya sebagai berikut.

\section{Tabel 7. Hasil Perhitungan Koefisien Determinasi (KD)}

\begin{tabular}{|c|c|c|c|}
\hline Variabel & $\begin{array}{l}\mathbf{r}^{2}- \\
\text { hitung }\end{array}$ & KD & Kesimpulan \\
\hline$\underset{\mathbf{Y}}{\mathbf{X}_{1} \Rightarrow}$ & 0,3295 & $\begin{array}{c}32,95 \\
\%\end{array}$ & $\begin{array}{c}\text { Bepengaruh } \\
\text { sebesar 32,95\% }\end{array}$ \\
\hline$\underset{\mathbf{Y}}{\mathbf{X}_{2} \Rightarrow}$ & 0,4422 & $\begin{array}{c}44,22 \\
\%\end{array}$ & $\begin{array}{c}\text { Bepengaruh } \\
\text { sebesar } 44,22 \%\end{array}$ \\
\hline $\begin{array}{l}\mathbf{X}_{1} \& \\
\mathbf{X}_{2} \Rightarrow \\
\mathbf{Y}\end{array}$ & 0,5200 & $\begin{array}{c}52,00 \\
\%\end{array}$ & $\begin{array}{c}\text { Bepengaruh } \\
\text { sebesar } 52,00 \%\end{array}$ \\
\hline
\end{tabular}

Kuesioner, Penelitian 2017

Berdasarkan hasil perhitungan koefisien determinasi yang terangkum dalam tabel di atas dapat disimpulkan bahwa besarnya pengaruh antara variabel kemampuan kerja pegawai $\left(\mathrm{X}_{1}\right)$ terhadap variabel kepuasan masyarakat (Y) sebesar $32,95 \%$ dan sisanya sebesar 67,05\% dipengaruhi oleh faktor lain. Besarnya pengaruh antara variabel kualitas

Vol 2, No 1 (2020) pelayanan $\left(\mathrm{X}_{2}\right)$ dengan variabel kepuasan masyarakat sebesar (Y) sebesar 44,22\% dan sisanya sebesar 55,78 \% dipengaruhi oleh faktor lainnya. Adapun apabila variabel kemampuan kerja $\left(\mathrm{X}_{1}\right)$ dan variabel kualitas pelayanan $\left(\mathrm{X}_{2}\right)$ secara bersama-sama akan berpengaruh terhadap variabel kepuasan masyarakat sebesar (Y) sebesar 52,00 \% dan sisanya sebesar $48,00 \%$ dipengaruhi oleh faktor lainnya yang menjadi epsilon dalam penelitian atau di luar variabel kepuasan kerja dan kualitas pelayanan.

Kemudian berdasarkan rumusan analisis regresi linear, maka hasil analisisnya dapat dirangkum ke dalam tabel berikut.

\section{Tabel 8. Hasil Perhitungan Regresi Linear Antara Kemampuan Kerja dengan Kepuasan}

\section{Masyarakat}

\begin{tabular}{|c|c|c|c|c|}
\hline & & oefficie & $n t s^{a}$ & \\
\hline \multirow{8}{*}{$\begin{array}{l}\text { Model } \\
1 \text { (Constan } \\
\text { t) } \\
\text {.X1 }\end{array}$} & \multirow{4}{*}{\multicolumn{2}{|c|}{$\begin{array}{c}\text { Unstandardiz } \\
\text { ed } \\
\text { Coefficients }\end{array}$}} & \multirow{5}{*}{$\begin{array}{c}\text { Standardiz } \\
\text { ed } \\
\text { Coefficient } \\
\text { s } \\
\end{array}$} & \multirow{6}{*}{$\begin{array}{l}\text { Si } \\
\text { g. }\end{array}$} \\
\hline & & & & \\
\hline & & & & \\
\hline & & & & \\
\hline & & Std. & & \\
\hline & B & Error & Beta & \\
\hline & \multicolumn{2}{|c|}{$10.621 \quad 2.299$} & & 9.000 \\
\hline & .575 & .083 & .574 & $\begin{array}{c}6.93 \\
1\end{array} .000$ \\
\hline
\end{tabular}

a. Dependent Variable: Y

Sumber : Hasil Analisis Data Kuantitatif Kuesioner, Penelitian 2017

Persamaan garis regresi linear antara kemampuan kerja $\left(\mathrm{X}_{1)}\right.$ terhadap kepuasan masyarakat $(\mathrm{Y})$ sebesar $\hat{\mathrm{Y}}=$ $10,621+0,575 X_{1}$. Persamaan garis ini memberikan interpretasi bahwa : Apabila variabel kemampuan kerja ditingkatkan sebesar satu unit skor maka akan meningkatkan (direspon positif) oleh variabel kepuasan masyarakat sebesar 0,575 unit skor ditambah nilai konstan sebesar 10,621. 


\section{Tabel 9. Hasil Perhitungan Regresi} Linear Antara Kualitas Pelayanan

\section{Masyarakat}

\section{dengan Kepuasan}

\begin{tabular}{|c|c|c|c|c|c|}
\hline \multirow{4}{*}{$\begin{array}{l}\text { Model } \\
1 \text { (Constan } \\
\text { t) } \\
\text { X2 }\end{array}$} & $\begin{array}{r}\text { Unstar } \\
\text { Coeff } \\
\end{array}$ & $\begin{array}{l}\text { dardiz } \\
\text { d } \\
\text { cients }\end{array}$ & $\begin{array}{c}\text { Standardiz } \\
\text { ed } \\
\text { Coefficient } \\
\text { s } \\
\end{array}$ & \multirow[b]{2}{*}{$\mathrm{t}$} & \multirow[b]{2}{*}{$\begin{array}{l}\mathrm{Si} \\
\text { g. }\end{array}$} \\
\hline & B & $\begin{array}{c}\text { Std. } \\
\text { Error }\end{array}$ & Beta & & \\
\hline & 9.578 & 1.932 & & $\begin{array}{c}4.95 \\
8\end{array}$ & .000 \\
\hline & .622 & .070. & .665. & $\begin{array}{c}8.82 \\
5\end{array}$ & .003 \\
\hline
\end{tabular}

a. Dependent Variable: Y

Sumber : Hasil Analisis Data Kuantitatif Kuesioner, Penelitian 2017

Hubungan diantara variabel kualitas pelayanan $\left(\mathrm{X}_{2}\right)$ dengan variabel kepuasan masyarakat ( $\mathrm{Y}$ ) pada tabel 4.21 yang tersaji di halaman sebelumnya dapat memenuhi persamaan garis regresi sebesar $\hat{\mathrm{Y}}=9,578+0,622 \mathrm{X}_{2}$. Persamaan garis ini memberikan interpretasi bahwa: Apabila variabel kualitas pelayanan ditingkatkan sebesar satu unit skor maka akan meningkatkan (direspon positif) oleh variabel kepuasan masyarakat sebesar 0,622 unit skor ditambah nilai konstan sebesar 9,578.

Tabel 10. Hasil Perhitungan Regresi Linear Antara Kemampuan Kerja

\section{Kualitas Pelayanan dengan Kepuasan Masyarakat}

\begin{tabular}{|c|c|c|c|c|}
\hline \multirow{5}{*}{$\begin{array}{l}\text { Model } \\
1 \text { (Constan } \\
\text { t) } \\
\text { X1 }\end{array}$} & \multicolumn{2}{|c|}{$\begin{array}{c}\text { Unstandardiz } \\
\text { ed } \\
\text { Coefficients }\end{array}$} & $\begin{array}{c}\text { Standardiz } \\
\text { ed } \\
\text { Coefficient } \\
\text { s }\end{array}$ & \multirow{3}{*}{$\begin{array}{ll} & \mathrm{Si} \\
\mathrm{t} & \mathrm{g} . \\
\end{array}$} \\
\hline & & Std. & & \\
\hline & B & Error & Beta & \\
\hline & 4.841 & 2.164 & & $\begin{array}{c}2.23 .028 \\
7\end{array}$ \\
\hline & .322 & .082 & .321 & $\begin{array}{c}3.95 .000 \\
1\end{array}$ \\
\hline $\mathrm{X} 2$ & .472 & .076 & .505 & $\begin{array}{c}6.21 .000 \\
5 \\
\end{array}$ \\
\hline
\end{tabular}

a. Dependent Variable: Y

Sumber : Hasil Analisis Data Kuantitatif Kuesioner, Penelitian 2017

Hubungan yang terjadi apabila variabel kemampuan kerja $\left(\mathrm{X}_{1}\right)$ dan variabel kualitas pelayanan $\left(\mathrm{X}_{2}\right)$ secara bersama-sama berhubungan terhadap variabel kepuasan masyarakat (Y) maka akan memenuhi persamaan garis regresi sebesar $\hat{Y}=4,481+0,322 X_{1}+0,472 X_{2}$. Persamaan garis ini memberikan interpretasi bahwa : Apabila variabel kepuasan kerja ditingkatkan sebesar satu unit skor maka akan meningkatkan (direspon positif) oleh variabel kepuasan masyarakat sebesar 0,322 unit skor, begitu pula dengan variabel kualitas pelayanan apabila ditingkatkan sebesar satu unit skor maka akan meningkatkan (direspon positif) oleh variabel kepuasan masyarakat sebesar 0,472 unit skor dan keduanya ditambah dengan nilai konstan sebesar 4,481.

Dengan hasil tersebut, maka dapat dikatakan bahwa berdasarkan persepsi responden variabel kemampuan kerja pegawai dan variabel kualitas pelayanan menjadi faktor penting dalam mempengaruhi variabel kepuasan masyarakat dalam menerima pelayanan publik di Kecamatan Karawaci Kota Tangerang, karena dengan semakin baiknya kepuasan kerja dan kualitas pelayanan di Kecamatan Karawaci Kota Tangerang maka akan meningkatkan tingkat kepuasan masyarakat dalam menerima pelayanan publik dari instansi ini.

\section{Kesimpulan Dan Saran}

Terdapat beberapa kesimpulan penelitian yang diajukan :

1. Hasil pengujian pertama yang menyatakan bahwa : Terdapat pengaruh kemampuan kerja pegawai terhadap kepuasan masyarakat dalam menerima pelayanan publik pada Kecamatan Karawaci Kota 
Tangerang", kesimpulannya dapat diterima pada selang kepercayaan 95\%. Dimana nilai korelasi antara kemampuan kerja pegawai dengan kepuasan masyarakat adalah 0,574 dengan tingkat signifikasi sebesar 0,000. Kemampuan kemampuan kerja pegawai mampu mempengaruhi kepuasan masyarakat di Kecamatan Karawaci sebesar sebesar 32,95\%. Sedangkan hubungan kemampuan kerja kerja dengan kepuasan masyarakat bersifat positif yang menghasilkan persamaan regresi linearnya adalah $\hat{\mathrm{Y}}=10,621+$ $0,575 \mathrm{X}_{1}$.

2. Hasil pengujian kedua yang menyatakan bahwa : Terdapat pengaruh kualitas pelayanan publik terhadap kepuasan masyarakat dalam menerima pelayanan publik pada Kecamatan Karawaci Kota Tangerang", kesimpulannya dapat diterima pada selang kepercayaan 95\%. Dimana nilai korelasi antara kualitas pelayanan dengan kepuasan masyarakat adalah 0,665 dengan tingkat signifikasi sebesar 0,000 . Kemampuan kualitas pelayanan dalam mempengaruhi kepuasan masyarakat di Kecamatan Karawaci sebesar sebesar 44,22 \%. Sedangkan hubungan kualitas pelayanan dengan kepuasan masyarakat bersifat positif yang menghasilkan persamaan regresi linearnya $\hat{Y}=9,578+0,622 X_{2}$.

3. Hasil pengujian ketiga yang menyatakan bahwa : Terdapat pengaruh kemampuan kerja pegawai dan kualitas pelayanan publik secara bersama-sama terhadap kepuasan masyarakat dalam menerima pelayanan publik pada Kecamatan Karawaci Kota Tangerang”, dapat terbukti pada selang kepercayaan 95 $\%$. Nilai korelasi antara kemampuan kerja pegawai dan kualitas pelayanan dengan kepuasan masyarakat adalah 0,721 dengan tingkat signifikasi sebesar 0,000. Kemampuan kepuasan kerja pegawai dan kualitas pelayanan dalam mempengaruhi kepuasan masyarakat di Kecamatan Karawaci sebesar sebesar 52,00\%. Sedangkan hubungan kemampuan kerja kerja dan kualitas pelayanan dengan kepuasan masyarakat bersifat positif yang menghasilkan persamaan regresi linearnya adalah $\hat{\mathrm{Y}}=4,481+0,322 \mathrm{X}_{1}$ $+0,472 X_{2}$.

Beberapa saran yang dapat diusulkan oleh peneliti berkenaan dengan hasil penelitian, antara lain :

1. Camat Karawaci harus memberikan kesempatan kepada pegawainya dalam rangka meningkatkan kemampuan kerja pegawai. Beberapa hal yang dapat meningkatkan kemampuan kerja pegawai saat ini adalah dengan memberikan kesempatan kepada pegawai untuk mau melanjutkan jenjang pendidikan formal yang ditamatkannya saat ini, minimal sampai dengan level sarjana. Peningkatan kemampuan kerja pegawai dapat juga dengan cara mengikutsertakan pegawai dalam kegiatan pendidikan dan latihan atau kepesertaannya dalam mengikuti bimbingan teknis penguasaan jenis pekerjaan tertentu sesuai dengan bidang tugas yang dimiliki oleh pegawai.

2. Camat Karawaci harus mampu meningkatkan kualitas pelayanannya saat ini. Kalau saat ini pelayanan di Kecamatan, khususnya dalam pelayanan non perijinan belum memiliki SOP maka Camat harus segera membuat SOP sesuai dengan jenis pelayanan, sehingga pemberian pelayanan kepada masyarakat dapat memiliki kepastian dan kepercayaan lebih dari masyarakat yang dilayaninya. Selain itu SOP yang dibuat harus ditaati oleh petugas pemberi pelayanan, jangan sampai SOP hanya dijadikan wacana tanpa dilaksanakan. 
3. Camat Karawaci disarankan agar melaksanakan evaluasi kepuasan masyarakat tiap tahun secara berkala yang berpedoman kepada Peraturan Menteri Pendayagunaan Aparatur Negara dan Reformasi Birokrasi Nomor 16 Tahun 2014 tentang Pedoman Survei Kepuasan Masyarakat Terhadap Penyelenggara Pelayanan Publik. Dengan adanya kegiatan ini, Camat dapat mengevaluasi kemampuan kerja pegawai, kualitas pelayanan sekaligus kepuasan masyarakat sebagai penerima layanan, sehingga Camat dapat mengantisipasi langkah-langkah yang harus dilaksanakan agar senantiasa kemampuan kerja pegawai, kualitas pelayanan dan kepuasan masyarakat dapat ditingkatkan dari tahun ke tahunnya.

4. Dalam hal optimalisasi dalam memberikan pelayanan terutama dalam mengatasi antrian pelayanan, Camat Karawaci seharusnya melakukan inovasi pelayanan dengan membuat sistem antrian kedatangan melalui aplikasi online sehingga pelayanan yang ada di Kecamatan Karawaci tidak terlihat menumpuk atau menunggu terlalu lama.

\section{Daftar Pustaka}

Djaenuri, Aries. 2005. Manajemen Pelayanan Umum. Jakarta: IIP Press.

Effendy, Onong Uchjana. 2002. Hubungan Masyarakat: Suatu Studi Komunikasi. Bandung: PT Remaja Rosda Karya.

Handayadiningrat, Suwarno, 2003. Pengantar Study Ilmu Administrasi dan Manajement, Gunung Agung, Jakarta.

Hasibuan, Malalyu SP. 2004. Manajemen Dasar, Pengertian, dan Masalah. Edisi Revisi. Bumi Aksara. Jakarta.

Moenir. 2008. Manajemen Pelayanan Umum Indonesia. Bumi Aksara Jakarta.

Ratminto dan Atik Septi Winarsih. 2009. Manajemen Pelayanan : Pengembangan Model Konseptual, Penerapan Citizen's Charter dan Standar Pelayanan Minimal. Pustaka Pelajar. Yogyakarta.

Siagian, P. Sondang. 2008. Manajemen Abad 21. Jakarta: Bumi Aksara.

Stoner, James A.F dan R. Edward Freeman. 2002. Manajemen. Edisi Keempat Jilid I. Intermedia. Jakarta.

Sugiyono. 2013. Metode Penelitian Kuantitatif Kualiatif dan $R \& D$,. Alfabeta. Bandung

Supriyanto, Eko dan Sri Sugiyanti. 2001. Operasionalisasi Pelayanan Prima. Jakarta: LANRI.

Tjiptono, Fandy. Manajemen Jasa. Andi Offset. Yogyakarta. 2001.

Thoha, Miftah. 2001. Perspektif Perilaku Birokrasi. Jakarta: Rajawali Press.

Umar, Husein. 2003. Metode Penelitian untuk Skripsi dan Tesis. Raja Grafindo. Jakarta.

Zauhar, Soesilo. 2006. Reformasi Administrasi: Konsep, Dimensi, dan Strategi. Jakarta: Bumi Aksara. 